\title{
Manatees and Crocodiles
}

\author{
fohn Charnock-Wilson
}

In the summer of 1969 the author returned to British Honduras, on a Churchill Fellowship, to follow up his previous studies of the manatee Trichecus manatus manatus and two crocodiles Crocodylus acutus and C. moreleti, all 'Red Book' species (see ORYX, May I968). He found a good breeding population of the manatee, but the plight of both crocodiles he describes as desperate.

The survey I had hoped to make of both crocodiles and manatees was nothing like as conclusive as I should have liked. I969 was one of the wettest summers on record in British Honduras, with Hurricane Anna on July 29th-3Ist, after which floods closed nearly all roads, including major ones, and culminating in Hurricane Francina on September $3 \mathrm{rd}$. One river was 32 feet above normal by mid-August. Moreover, the prohibitive charges for boat-hire made it impossible for me to study the offshore islands. I had intended to swim with the manatees and photograph them underwater, but the exceptional rain brought down so much soil in the rivers that water which had been crystal clear in I967 was so murky that visibility was a couple of feet. In the circumstances it was impossible to make an accurate population estimate. However, I saw manatees wherever I was able to investigate, though not close enough to be able to photograph them. There seemed to be a good breeding population, and if predation can be kept in check the future of the manatee in British Honduras seems good. Protection legislation exists, but no one seems to know what it says, except that the sale of manatee meat on the open market is illegal. One person I spoke to was convinced that by paying a fee of $\$ 2,50$ (I2s $6 \mathrm{~d}$ ) he would get a licence to hunt as many manatee as he required. Thankfully, due to the problems of finding, catching, butchering and preserving so large an animal, there is little active predation.

Information on the crocodiles $C$. acutus and $C$. moreleti was much more difficult to come by, but there is no doubt that their situation is serious. It is very difficult to get any idea of the distribution at first hand, and I had to rely on what villagers told me. Undoubtedly there is a good trade in the skins, for, although it is apparently illegal to export live animals without a permit, there seems to be no law to stop the skins being made into handbags and exported. Any native person with a gun can be guaranteed to shoot any animal he comes across. The price for a good skin is $f \mathrm{I} I 7 \mathrm{~s} 6 \mathrm{~d}$ per foot, so that an average crocodile can earn a man a week's wages for the expenditure of a cartridge-and there are plenty of Americans and locals who will gladly buy every skin they can get. The crocodile export trade is believed to be in the region of $\$ 23,000$, or about 3,000 ft of crocodile, and this figure, of course, is only for skins going through the regular channels; it makes no allowance for those exported illegally, or those which are wounded and never recover. 
The result is that the plight of the crocodiles, especially $C$. acutus, is desperate in the extreme. Reliable reports show that before the I96I hurricane the isolated island of Northern Caye was infested with $C$. acutus. But now, according to the local customs men who regularly visit the lighthouse on this island, it is rare to find any animal over $3 \mathrm{ft}$ long. I can remember ten years ago seeing many brought in by fishermen from the Drown Cayes, off Belize, but this trade is now finished and it is no longer worthwhile to hunt them in this region. Undoubtedly some exist; there are islands sufficiently remote for there to be unreported populations, but whether there is a breeding population anywhere in the colony is questionable. The increasing use of power boats is driving the animal from many of its familiar habitats.

\section{They No Longer Sit and Stare}

The situation of $C$. moreleti is no happier. Not only does every farmer and villager today have a gun and the money to buy cartridges, but many rivers are now traversed in their lower reaches by motorboats, and inland swamps are increasingly used for paddyfields. British Honduras is increasingly being advertised as a big game country, and more and more unscrupulous hunters are moving in for the kill. The depletion over the last 20-25 years is well demonstrated in the mouth of the Belize River. During and after the last war, it was normal to see ro-rs ft crocodiles lying under the Haulover Bridge (this carries the busiest road in the country from the capital to the airport). Mahogany contractors spoke of animals interfering with logging and rafting operations, and on taking a boat from the capital up the Belize River one could normally count on finding at least one or two animals along the bank or in the river. Today there are none. Ivan Sanderson in his book "Living Treasure" (194I) on the wildlife of the colony, refers to the younger crocodiles being 'very numerous along the roadsides in the big ditches and easily captured ... apparently they were so used to traffic passing along the road that they simply sat and stared at us.' This is certainly no longer the case, and one has to be very lucky or very industrious to get a sight of one. Even travelling the rivers of the Gulf of Honduras region-rivers which are uninhabited for most of their length and which probably do not see more than half-a-dozen people in the course of a year-we saw only one baby in a week of intensive search, and this certainly did not sit and stare at us.

Other animals in British Honduras are also in danger, especially the cats and deer among the larger game animals. The country is now divided into concessions, leased by the government at ridiculously low fees to 'hunters' who drive around Belize in neatly ironed bush jackets and zebra-painted jeeps. There have been authenticated cases of jaguars being trapped in one area, transported to another, and released under the nose of trigger-happy 'dudes'. There are official quotas, and bounties to be paid on each animal shot, but there is no way of insuring that all are recorded. At least one hunter had his licence revoked for falsification of reports, and another boasted that, together with an American, he had accounted for I20 jaguars on the Guatemala border. 
Nor is it encouraging to hear officers of the British garrison announcing their intention of hunting crocodiles with self-loading rifles. The smaller mammals and reptiles would seem to be in a happier position; there is no export trade for them as pets, and their food value is small. Nevertheless, the once numerous iguana is now something of a rarity, due, I believe, to its flavour and the excellent target it makes.

One sideline I tried to follow up was the question of the monk seal Monachus tropicalis, which I had heard inhabited Chinchorro Reef, a large atoll in Mexican waters. But no-one in Chetumal, capital of the province involved, could confirm the rumour. I chartered a plane and buzzed the place extensively in the hope of seeing something which would justify a full-scale expedition. Although from an altitude of about $50 \mathrm{ft}$ we could see every detail of the seabed, sharks and schools of quite small fish, no Caribbean monk seals were to be seen.

\section{Everglades Saved from a Jetport}

The vast international airport planned for a site on the edge of the Everglades National Park, in Florida, is to be built elsewhere and the existing pilot-training strip is to be closed down-a big victory for US conservationists. But the problem of the water-flow through the park remains; the Army Corps of Engineers has still to be persuaded to allow the park a fair share.

\section{A Furrier and the Rare Furs}

'We refuse to be responsible in any way for the possible extinction of any animal species', says an advertisement in the Nerw York Times by the furrier, Georges Kaplan. He calls on 'all enlightened furriers' to make the furs of endangered animals unfashionable. Furriers who sign a pledge not to trade in ten endangered species-leopard, tiger, cheetah, polar bear, Spanish lynx, jaguar, red wolf, sea otter, ocelot and vicuña-will be given a WWF seal of approval, and Kaplan promises to publish a list of the signatories.

\section{Black Rhinos Settle Down}

The Kenya Game Department's policy of moving black rhinos from areas where their habitat was being destroyed by agriculture to the Nairobi National Park, has proved a success. Eighteen of the 22 animals moved appear to have settled down, and visitors to the park now have a better chance of seeing black rhino. Two rhinos died, and two were not seen in the follow-up surveys made by P. H. Hamilton and J. M. King, who describe the results in the East African Wildlife fournal, volume 7. Only one serious fight with a resident rhino is recorded, and only two cases of car-chasing ended in a 'hit' being scored: in one the rhino had been provoked by another car driver, and the second was the result of a carrhino meeting on a blind bend.

\section{Home of Lord Derby's Eland}

Senegel has published an illustrated Guide in English to the NiokoloKoba National Park. The sixty species of mammals in the park include the western giant eland (Lord Derby's eland) now found in only two other areas (in Mali and Guinea), and a highly endangered species. The park has a 30 -bed hotel and an air strip, with weekly planes from Dakar. 